удк 658.155

\title{
АНАЛІЗ ЛЕВЕРИДЖУ ЯК СИСТЕМИ УПРАВЛІННЯ ВИТРАТАМИ ТА ПРИБУТКОМ В УМОВАХ НЕВИЗНАЧЕНОСТІ
}

\section{ANALYSIS OF LEVERAGE AS THE SYSTEM OF COST AND PROFITABILITY MANAGEMENT UNDER UNCERTAINTY}

\author{
Руденко Інна Вікторівна \\ кандидат економічних наук, доцент, \\ Харківський торговельно-економічний коледж \\ Київського національного торговельно-економічного університету \\ ORCID: https://orcid.org/0000-0001-5940-2344 \\ Rudenko Inna \\ Kharkov College of Trade and Economics \\ Kiev National University of Trade and Economics
}

\begin{abstract}
У статті обґрунтована актуальність методів аналізу, орієнтованих на управління витратами та прибутком 3 урахуванням ризику. Розглянута методика аналізу левериджу за окремими видами продукції. Розроблено методику прогнозного аналізу, в основі якої лежать категорії левериджу, що враховує ступінь чутливості показників за рахунок застосування відносних величин - індикаторів виробничого й фрінансового ризику. Здійснено апробацію рекомендованої прогностичної моделі на матеріалах підприємства харчування - ТОВ «Блиск». Представлено розрахунки прогнозних даних кінцевого фрінансового результату в розрізі окремих найменувань страв з підрахунком його величини в цілому по підприємству. Для оцінки якості прогнозу за даними досліджуваного нами підприємства була обчислена відносна похибка прогнозу, результати якої дали можливість запропоновану методику прогнозного аналізу рекомендувати до застосування.
\end{abstract}

Ключові слова: аналіз, ризик, виробничий леверидж, фрінансовий леверидж, управління, витрати, прибуток, прогнозування.

В статье обоснована актуальность методов анализа, ориентированных на управление затратами и прибылью с учетом риска. Рассмотрена методика анализа левериджа по отдельным видам продукции. Разработана методика прогнозного анализа, в основе которой лежат категории левериджа, учитывающая степень чувствительности показателей за счет применения относительных величин - индикаторов производственного и финансового риска. Осуществлена апробация рекомендуемой прогностической модели на материалах предприятия питания - ООО «Блеск». Представлены расчеты прогнозных данных конечного фрінансового результата в разрезе отдельных наименований блюд с подсчетом его величины в целом по предприятию. Для оценки качества прогноза по данным изучаемого нами предприятия была исчислена относительная погрешность прогноза, результаты которой позволили предложенную методику прогнозного анализа рекомендовать к применению.

Ключевые слова: анализ, риск, производственный леверидж, финансовый леверидж, управление, расходы, прибыль, прогнозирование.

The aim of the article is to study the methodological foundations of analysis and forecasting of leverage as a system of cost and profit management of certain products. The relevance of risk-oriented cost-benefit analysis methods is substantiated. Theoretical analysis of the opinions given in the scientific literature on the essence of the concepts of leverage and their importance in the organization and management of financial results. It is concluded that the literature does not pay enough attention to methodological approaches to forecasting changes in profits in terms of individual products. The essence of the concepts of production (operational), financial and production-financial (aggregate) leverage is clarified. It is proved that in the conditions of uncertainty of market situations in Ukraine and their rather rapid changes, a more flexible approach to the use of certain methods of managing financial indicators becomes necessary. A methodical approach to the analysis of leverage for certain types of products has been developed, which will allow quickly manage both costs and profits of the enterprise. It is emphasized that according 
to this method of calculation, the level of production leverage is determined by the cost structure and the volume of demand for products, which ultimately determines the degree of flexibility of the enterprise. Emphasis is placed on the expediency of using the considered methodological approach to calculate the impact of levels of operational and financial leverage and the amount of consumer demand on the net profit of the enterprise. A method of forecast analysis of profit has been developed, which is based on the categories of leverage, which takes into account the degree of sensitivity of indicators through the use of relative values - indicators of production and financial risk. Approbation of the recommended prognostic model on the materials of the food company - LLC "Blysk" was carried out. The calculations of forecast data of the final financial result in the context of individual names of dishes with the calculation of its value as a whole for the enterprise are presented. To assess the quality of the forecast, according to the company we studied, the relative error of the forecast was determined, the results of which made it possible to recommend the proposed method of forecast analysis for use.

Keywords: analysis, risk, production leverage, financial leverage, management, expenses, profit, forecasting.

Постановка проблеми. В умовах нестабільності та невизначеності, які ми спостерігаємо останнім часом в Україні, завдання економічного аналізу розширюються і поглиблюються. Створюються об'єктивні передумови для його відтворення на новій основі, для його націленості на перспективу. Зокрема актуальним стає потреба зміни характеру аналітичних досліджень 3 метою розширення зони діагностики та пошуку.

Втім в умовах конкуренції виникає необхідність в розробці методів і прийомів, орієнтованих на управління витратами та прибутком 3 урахуванням ризику. Одним із сучасних підходів в цьому напрямку $є$ використання категорії левериджу. Особливо актуальне значення набувають питання зміни величини прибутку в залежності від зміни об'єму реалізації, співвідношення витрат або ринкової ціни, а також можливості прогнозування фрінансових результатів підприємства в умовах невизначеності.

Аналіз останніх досліджень і публікацій. Категорії левериджу та його впливу на фрінансові результати підприємства $є$ предметом пильної уваги науковців і практиків. Вагомий внесок у вирішення й розробку методики аналізу левериджу в управлінні витратами та прибутком внесли такі вітчизняні вчені, як І. А. Бланк, В. О. Подольська, О. В. Яріш, Л. А. Лахтіонова, Л. С. Крючко, О. В. Добровольська, Н. П. Дуброва, Н. Й. Радіонова, О. В. Короткова, Л. П. Довгань, М. С. Клішина, О. П. Заборовець, В. В. Усатюк та ін. Серед зарубіжних вчених слід назвати Ван Хорна Дж. К., В. В. Ковалева, А. Д. Шеремета, $€$ Є. С. Стоянову, Є. Ф. Брігхема, О. В. Тернових та інших.

У роботах більшості перелічених авторів висвітлюються питання організації та управління фрінансовими результатами в ринкових умовах, а також фрактори, що на них впливають. Проте $€$ певні особливості, на які слід звернути увагу. Колектив зарубіжних авторів концепцію левериджу пов'язує 3 досягнен- ням більшого результату за докладання менших зусиль. Він вважає леверидж своєрідним ключем до успіху в бізнесі, який дає змогу постійно отримувати плату за лише один раз зроблену роботу $[1$, с. 38].

Ван Хорн Дж. К. вважає, що операційний леверидж не варто розглядати як показник підприємницького ризику компанії. На його думку - це лише один 3 компонентів сукупного ризику, який не є основним. Основними ж фракторами, які збільшують підприємницький ризик, є невизначеність обсягу продажу та витрат виробництва [2, с. 381].

Низка авторів розглядають операційний леверидж як ключову складову операційного аналізу «Витрати-Обсяг-Прибуток» [3; 4; 5]. На їх думку, сила дії операційного важеля показує міру чутливості валового прибутку до змін фрізичного обсягу реалізації продукції [5, с. 182].

В. В. Ковальов категорію левериджу характеризує як процес управління активами, який спрямований на зростання прибутку [6, с. 303]. Як інструмент фрінансового менеджменту розглядають леверидж й такі автори як Л. П. Довгань, М. С. Клішина [7], О. П. Заборовець, В. В. Усатюк [8], О. В. Тернових [9] тощо.

Вирішення невирішених раніше частин загальної проблеми. Віддаючи належне науковим напрацюванням вітчизняних та зарубіжних вчених, слід відзначити, що питання прогнозної оцінки фрінансових результатів потребують удосконалення й подальшого наукового дослідження. Значною мірою це зумовлено тим, що у літературних джерелах недостатньо приділена увага методичним підходам щодо складання прогнозу зміни прибутку в розрізі окремих видів продукції. Крім того, в умовах невизначеності ринкових ситуацій та їх досить швидкоплинних змін, що все більш спіткають економіку України, стає необхідним більш гнучкий підхід до використання тих чи інших методів управління фрінансовими показниками. Це зумовило актуальність і цільову спрямованість дослідження. 
Формулювання цілей статті (постановка завдання). Метою статті є дослідження методичних основ аналізу й прогнозування левериджу як системи управління витратами та прибутком окремих видів продукції.

Відповідно до мети, завданнями наукового дослідження є:

- уточнення методики аналізу левериджу за окремими видами продукції, який дозволить оперативно управляти як витратами, так і прибутком підприємства;

- розробка методики прогнозного аналізу, в основі якої лежать категорії левериджу;

- апробація рекомендованої прогностичної моделі на матеріалах підприємства харчування та оцінка якості прогнозу.

Виклад основного матеріалу дослідження. Одним із механізмів мінімізації витрат і максимізації прибутку є використання категорії левериджу. У буквальному розумінні леверидж означає «невелику силу, важель, за допомогою якого надається можливість переміщувати досить великі предмети» [10, с. 313]. В економіці він трактується як деякий фрактор, невелика зміна якого може призвести до істотної зміни кінцевих показників.

Відомо три види левериджу: виробничий (операційний), фрінансовий та виробничоорінансовий (сукупний). Виробничий (операційний) леверидж $є$ оцінкою виробничого (господарського, операційного) ризику, пов'язаного 3 конкретним бізнесом в його ринковій ниші. Виробничий ризик обумовлюється нестійкістю попиту й цін на продукцію, а також цін і тарифрів на сировину, енергію та інші елементи витрат. Нестійкість фрінансових умов кредитування обумовлює виникнення фрінансового ризику, який вимірюється за допомогою рівня фрінансового левериджу. Всі три категорії левериджу виникають в процесі фрормування кінцевих фрінансових результатів діяльності підприємств.

Методика обчислення виробничого, фрінансового та сукупного левериджу загальновідома [8; 10; 11; 12; 13]. Втім хотілося б звернути увагу на особливості розрахунку рівня виробничого левериджу за окремими видами продукції, який дозволить оперативно управляти як витратами, так і прибутком підприємства (фрормула 1):

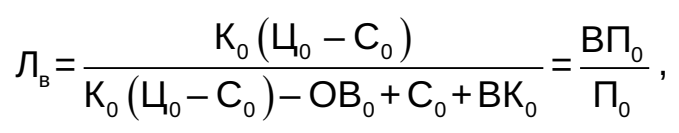

де $\mathrm{K}_{0}$ - кількість реалізованої продукції в базисному періоді, од.;

$Ц_{0}, \mathrm{C}_{0}$ - ціна реалізації і собівартість на одиницю продукції в базисному періоді, грн.;
$\mathrm{OB}_{0}$ - операційні витрати виробництва та обігу окремих видів продукції базисного періоду, грн.;

$\mathrm{C}_{0}$ - сальдо доходів і витрат від іншої реалізації і позареалізаційних операцій окремих видів продукції в базисному періоді, грн..;

$\mathrm{BK}_{0}$ - відсотки за кредит окремих видів продукції в базисному періоді, грн.;

ВП 0 - валовий прибуток окремих видів продукції в базисному періоді, грн;

$\Pi_{0}$ - прибуток до сплати відсотків за кредит і податків окремих видів продукції, грн.

У цьому випадку рівень виробничого левериджу обумовлюється структурою витрат та обсягом попиту на продукцію, що в кінцевому рахунку зумовлює ступінь гнучкості підриємства. Якщо рівень постійних витрат високий і не знижується в період спаду попиту на продукцію, підприємницький ризик збільшується. Таким чином, з'являється «потенційна можливість підприємства впливати на темпи зміни операційного прибутку шляхом зміни обсягів і структури операційних витрат (постійних і змінних)» [7, с. 168]. Вплив рівней операційного та фрінансового левериджа та розміру попиту на чистий прибуток визначається за наступною формулою:

$$
t \Delta \sqcup \Pi=\Omega_{\mathrm{B}} \times \Omega_{\phi} \times t \Delta \mathrm{OP},
$$

де $t \Delta$ ЧП - темп зміни чистого прибутку (збитку) окремих видів продукції,\%;

$\Omega_{\text {в }}$ - рівень виробничого левериджу окремих видів продукції, од.;

$\Omega_{\phi}-$ рівень фрінансового леверіджу окремих видів продукції, од.;

$t \Delta \mathrm{OP}$ - темп зміни фрізичного обсягу реалізації окремих видів продукції, \%.

Використання запропонованої методики аналізу дасть можливість оперативного управління прибутком окремих видів продукції шляхом: маневрування ціною, зміни структури витрат та їх скорочення у разі потреби, здійснення оптимальної політики фрормування капіталу підприємства, залучення попиту споживачів. Це, в свою чергу, дозволить підприємствам своєчасно адаптуватися до змін ринкової кон'юнктури і разом 3 тим уникнути невиправданого ризику.

Крім того, дана методика аналізу прибутку може бути застосована для цілей прогнозування.

Відомо, що для цілей оперативного управління прибутком підприємств потрібна перш за все простота методів та економічність розрахунків, що дасть можливість знайти застосування їм в практичній діяльності. Крім того, останнім часом усе більший інтерес представляє прогноз, який складений для конкретного 
товару або продукту. Тому з метою розробки політики щодо управління виробництвом окремих видів продукції потрібно проведення аналізу попиту й пропозиції. Для такого напряму застосувань прогностичні методи й моделі мають бути легкими у використанні та гнучкими.

Задовольняє викладеним вище вимогам оперативного управління витратами й прибутком методика прогнозного аналізу, в основі якої лежать категорії левериджу. Якщо на підприємстві складається управлінська звітність і проводиться оцінка ступенів ризику 3 аналізом їхнього впливу на кінцеві фрінансові результати, то прогнозування прибутку буде здійснюватися за допомогою наступної фрормули:

$$
4 \Pi^{\Pi \mathrm{P}}=4 \Pi^{\Phi}\left(1+\Omega_{\mathrm{B}} \times \Omega_{\Phi} \times t \Delta \mathrm{OP} \mathrm{P}^{\Pi \mathrm{P}}\right),
$$

де ч $\Pi^{\Phi}$ - фрактичне значення чистого прибутку (збитку), тис. грн.;

чП ПР - прогнозний чистий прибуток, тис. грн.;

$t \Delta \mathrm{OP}^{П Р}$ - прогнозний темп зміни фрізичного обсягу реалізації, коефр.

Використання даної прогностичної моделі зручно перш за все тому, що в розрахунках приймає участь прогнозне значення показника лише за один (останній) проміжок часу. Таким чином усувається вплив інсрляції, сезонності та інших фракторів, які проявляють свій вплив в динаміці. Це особливо важливо в умовах нестачі інсрормації або складності її отримання. Крім того, модель враховує ступінь чутливості показників за рахунок застосування відносних величин, які $є$ індикаторами виробничого й фрінансового ризику. Кінцевий фрінансовий результат, фрактично досягнутий підприємством, корегується також на прогнозні зміни попиту споживачів, що особливо важливо в умовах конкурентної непередбачуваності. Запропонована методика розрахунку дозволить не тільки визначати майбутні кінцеві результати діяльності підприємства, але й за можливістю управляти ними.

Рекомендована методика прогнозного аналізу була апробована нами на матеріалах підприємства харчування - ТОВ «Блиск». Прогноз кінцевого фрінансового результату здійснювався в розрізі окремих найменувань страв $з$ підрахунком його величини в цілому по підприємству. Отримані результати розрахунків наведені в таблиці 1.

Про можливості застосування запропонованої моделі в прогностичних цілях можливо говорити, оцінивши якість прогнозу. Найбільш розповсюдженими показниками оцінки якості прогнозу, як відомо, $є$ середньоквадратична похибка, абсолютна й середня абсолютна похибки, відносна й середня відносна похибки. Перші показники мають недолік, який полягає в тому, що їхнє значення істотно залежить від масштабу вимірювання рівнів досліджуваних явищ. Тому найбільш прийнятною, на нашу думку, є відносна похибка прогнозу, яку ми розрахували за даними досліджуваного нами підприємства, за кожний місяць другого півріччя 2021 року. Результати розрахунків наведені в таблиці 2.

Як показали розрахунки, відносна похибка прогнозу не перевищує припустимі для короткострокового прогнозу межі (5-10\%). Таким чином запропонована методика прогнозного аналізу може бути рекомендована до застосування.

Розрахунок прогнозних значень фрінансових результатів ТОВ «Блиск»

Таблиця 1 на грудень 2021 року

\begin{tabular}{|l|c|c|c|c|}
\hline Найменування страв & $\begin{array}{c}\text { Чистий } \\
\text { прибуток } \\
\text { за листопад, } \\
\text { тис. грн. }\end{array}$ & $\begin{array}{c}\text { Рівень } \\
\text { левериджу при } \\
\text { зміні попиту } \\
\text { від жовтня до } \\
\text { листопада, од. }\end{array}$ & $\begin{array}{c}\text { Прогнозний } \\
\text { темп зміни } \\
\text { обсягу } \\
\text { реалізації на } \\
\text { грудень, коеф. }\end{array}$ & $\begin{array}{c}\text { Прогнозне } \\
\text { значення } \\
\text { чистого } \\
\text { прибутку } \\
\text { за грудень, } \\
\text { тис. грн. }\end{array}$ \\
\hline 1. Буженина & 67,9 & 2,55 & 0,05 & $+76,6$ \\
\hline 2. Асорті з свіжих овочів & $-8,8$ & 60,8 & 0,05 & $-35,5$ \\
\hline 3. Булка бутербродна & -47 & $-2,89$ & 0,01 & $-45,6$ \\
\hline 4. Котлета по-київські & +202 & 2,51 & 0,20 & $+303,4$ \\
\hline 5. Піцца & $-7,9$ & $-9,74$ & 0,05 & $-4,0$ \\
\hline 6. Картопля фррі & $-72,3$ & $-2,27$ & 0,15 & $-47,7$ \\
\hline 7. Салат «Фантазія» & $+195,1$ & 3,03 & 0,05 & $+224,7$ \\
\hline 8. Чай & $-39,0$ & 38,58 & 0 & $-39,0$ \\
\hline Разом & & & & $+432,0$ \\
\hline
\end{tabular}


Таблиця 2

Прогноз фрінансових результатів ТОВ «Блиск» та оцінка його адекватності за II півріччя 2021 року

\begin{tabular}{|l|c|c|c|}
\hline \multicolumn{1}{|c|}{ Періоди часу } & $\begin{array}{c}\text { Фактичний чистий } \\
\text { прибуток, тис. грн. }\end{array}$ & $\begin{array}{c}\text { Розрахункове } \\
\text { значення чистого } \\
\text { прибутку, тис. грн. }\end{array}$ & $\begin{array}{c}\text { Відносна похибка } \\
\text { прогно3у, \% } \\
\text { (гр.2-гр.3)/гр.2*100 }\end{array}$ \\
\hline $\mathbf{1}$ & $\mathbf{2}$ & $\mathbf{3}$ & $\mathbf{4}$ \\
\hline Липень & $-267,2$ & $-258,0$ & 3,4 \\
\hline Серпень & $+296,9$ & $+305,4$ & 2,9 \\
\hline Вересень & $-200,8$ & $-193,4$ & 3,7 \\
\hline Жовтень & $+223,0$ & $+232,8$ & 4,4 \\
\hline Листопад & $+290,0$ & $+303,2$ & 4,55 \\
\hline Грудень & $+412,0$ & $+432,0$ & 4,85 \\
\hline Разом ІІ півріччя & & & 3,97 \\
\hline
\end{tabular}

Висновки. Аналіз показників левериджу, запропонований у проведеному дослідженні, $€$ дієвим інструментом контролю над доходами й витратами, ефеективним напрямом планування прибутку підприємства. Він може використовуватися для оперативного управління процесом фрормування прибутку окремих товарів або видів продукції. Його практична значимість зростатиме у випадках, коли потрібно приймати управлінські рішення на основі оцінки можливих ситуацій та робити вибір між деякими альтернативними варіантами. Це збільшить можливості оперативного управління прибутком в умовах невизначеності та дозволить швидко адаптуватися до мінливих умов фрункціонування підприємств на вітчизняному ринку.

\section{СПИСОК ВИКОРИСТАНИХ ДЖЕРЕЛ:}

1. D. Septiari, A. Hasbi Nasution. Analysis of the Influence of Financial Leverage on Financial Performance at Mining, Oil and Gas Companies Listed jn Indonesia Stock Exchange. Journal of Applied Accountihg and Taxation. 2017. 2(1). P. 37-41. URL: https://jurnal.polibatam.ac.id/index.php/JAAT/article/view/546

2. Ван Хорн Дж. К. Основы управления фрінансами / пер. с англ. Я. В. Соколов. Москва : Финансы и статистика, 2005. 800 с.

3. Короткова О. В. Можливості використання операційного левериджу в аналізі ефективності управління рекреаційним підприємством. Ефрективна економіка. 2013. № 5. URL: http://www.economy.nayka.com.ua/ ?op $=1 \& z=2007$

4. Радіонова Н. Й. Вплив механізму виробничого левериджу на управління витратами промислового підприємства. Вісник соціально-економічних досліджень. 2018. № 1. C. 119-124. URL: http://vsed.oneu.edu.ua/ collections/2018/65/pdf/119-124.pdf

5. Стоянова Е. С. Финансовый менеджмент: теория и практика : учебник. Москва : Перспектива, 2010. 656 с.

6. Ковалев В. В. Финансовый анализ: Управление капиталом. Выбор инвестиций. Анализ отчетности. Москва : Финансы и статистика, 2009. 512 с.

7. Довгань Л. П., Клішина М. С. Використання прийомів і інструментів фінансового менеджменту для забезпечення підвищення вартості корпоративних прав (на прикладі ПАТ «Арселорміттал Кривий Ріг»). Бізнес навігаmор. 2019. Вип. 6.1-1(56). С. 163-171. URL: http://www.business-navigator.ks.ua/journals/2019/56_1_2019/30.pdf

8. Заборовець О. П., Усатюк В. В. Вплив механізму виробничого левериджу на прибуток підприємства. Сучасні проблеми економіки та підприємництво. 2014. № 13. С. 242-247. URL: http://sb-keip.kpi.ua/article/view

9. Терновых Е. В. Формирование ефективного механизма управления фрінансами предприятия на основе левериджа. Вестник Воронежского государственного аграрного университета. 2017. № 2(53). С. 186-196. URL: http://vestnik.vsau.ru/wp-content/uploads/2017/09/186-196.pdf

10. Лахтіонова Л. А. Фінансовий аналіз суб'єктів господарювання : монографрія. Київ : КНЕУ, 2011. 387 с.

11. Добровольська О. В., Дуброва Н. П. Сутність операційного левериджу та методика його розрахунку. Причорноморські економічні студіï. 2021. Випуск 62. С. 124-128. URL: http://bses.in.ua/journals/2021/62_ 2021/22.pdf

12. Крючко Л. С., Бережко Я. В., Семиліт І. В. Використання операційного левериджу в управлінні прибутком підприємства. Економічна наука. 2016. № 7. С. 67-70. URL: https://essuir.sumdu.edu.ua/economica_06_2016

13. Подольська В. О., Яріш О. В. Фінансовий наліз : навч. посіб. Київ : Центр навчальної літератури, 2007. 488 с. 


\section{REFERENCES:}

1. Septiari, D., \& Hasbi Nasution, A. (2017) Analysis of the Influence of Financial Leverage on Financial Performance at Mining, Oil and Gas Companies Listed jn Indonesia Stock Exchange. Journal of Applied Accountihg and Taxatio, 2(1), 37-41. Available at: https://jurnal.polibatam.ac.id/index.php/JAAT/article/view/546 (accessed 17 January 2022).

2. Khorn, V. D. K. (2005) Osnovy upravlenyia finansamy [Fundamentals of financial management]. Moscow: Fynansy y statystyka. (in Russian)

3. Korotkova O. (2013) Mozhlyvosti vykorystannia operatsiinoho leverydzhu v analizi efektyvnosti upravlinnia rekreatsiinym pidpryiemstvom [The possibility of using operating leverage in the analysis of the control quality management of the recreational enterprise]. Efektyvna ekonomika, no 5, Available at: http://www.economy.nayka.com.ua/ ?op=1\&z=2007 (accessed 13 January 2022). (in Ukrainian)

4. Radionova, N. Y. (2018) Vplyv mekhanizmu vyrobnychoho leverydzhu na upravlinnia vytratamy promyslovoho pidpryiemstva [Influence of production leverage mechanism on cost management of industrial enterprise]. Visnyk sotsialno-ekonomichnykh doslidzhen, no. 1(65), 119-124. Available at: http://vsed.oneu.edu.ua/collections/2018/65/ pdf/119-124.pdf (accessed 12 January 2022). (in Ukrainian)

5. Stoianova, E. S. (2010) Fynansovyi menedzhment: teoryia y praktyka [Financial management: theory and practice]. Moscow: Perspektyva. (in Russian)

6. Kovalev, V. V. (2009) Fynansovyi analyz: Upravlenye kapytalom. Vubor ynvestytsyi. Analyz otchetnosty [Financial Analysis: Capital Management. Investment choice. Reporting analysis]. Moscow: Fynansy y statystyka. (in Russian)

7. Dovhan, L. P., \& Klishyna, M. S. (2019) Vykorystannia pryiomiv i instrumentiv finansovoho menedzhmentu dlia zabezpechennia pidvyshchennia vartosti korporatyvnykh prav (na prykladi PAT «Arselormittal Kryvyi Rih»). [Dovgan Ludmila, Klishina Marina. Using techniques and tools of financial management to ensure an increase in the value of corporate rights (for example, JSC "ArcelorMittal Krivoy Rog")]. Biznes navihator, no. 6.1-1(56), 163-171. Available at: http://www.business-navigator.ks.ua/journals/2019/56_1_2019/30.pdf (accessed 13 January 2022). (in Ukrainian)

8. Zaborovets, O. P., \& Usatiuk, V. V. (2014) Vplyv mekhanizmu vyrobnychoho leverydzhu na prybutok pidpryiemstva [The impact of the production mechanism of leverage on profits of the enterprise]. Suchasni problemy ekonomiky ta pidpryiemnytstvo, no. 13, 242-247. Available at: http://sb-keip.kpi.uaarticlesview (accessed 12 January 2022). (in Ukrainian)

9. Ternovykh, E. V. (2017) Formyrovanye efektyvnoho mekhanyzma upravlenyia finansamy predpryiatyia na osnove leverydzha [Formation of an efficient mechanism of financial management in enterprises based on leverage]. Vestnyk Voronezhskoho hosudarstvennoho ahrarnoho unyversyteta, no. 2(53), 186-196. Available at: http://vestnik.vsau.ru/wp-content/uploads/2017/09/186-196.pdf (accessed 13 January 2022). (in Russian)

10. Lakhtionova, L. A. (2011) Finansovyi analiz subiektiv hospodariuvannia [Financial analysis of business entities]: monohrafiia [a monograph]. Kyiv: KNEU. (in Ukrainian)

11. Dobrovolska, O. V., \& Dubrova, N. P. (2021) Sutnist operatsiinoho leverydzhu ta metodyka yoho rozrakhunku. [The nature of operational leverage and method of its calculation]. Prychornomorski ekonomichni studii, no. 62, 124-128. Available at: http://bses.in.ua/journals/2021/62_2021/22.pdf (accessed 14 January 2022). (in Ukrainian)

12. Kriuchko, L. S., Berezhko, Y. V., \& Semylit, I. V. (2016) Vykorystannia operatsiinoho leverydzhu v upravlinni prybutkom pidpryiemstva. [Use operation leveredzhu in management of enterprise income]. Ekonomichna nauka, no. 7, 67-70. Available at: https://essuir.sumdu.edu.ua/economica_06_2016 (accessed 14 January 2022). (in Ukrainian)

13. Podolska, V. O., \& Yarish, O. V. Finansovyi analiz [Financial analysis]. Kyiv: Tsentr navchalnoi literatury. (in Ukrainian) 